\title{
Retrofitting Listed Buildings: Measures, Savings and Requirements
}

\author{
Torben Valdbjørn Rasmussen*
}

Danish Building Research Institute, Department of Construction and Health at Aalborg University, Hфrsholm, Denmark

\begin{abstract}
The paper presents a case study where the energy demand for a listed building constructed in 1900 is reduced. Many older buildings are listed and have restrictions that include the entire building or that include only its exterior. For the building presented, only its exterior facade is listed. The paper demonstrates measures for the improvement of the thermal insulation of the building with solid brick walls. Durable customised measures are shown. The customised measures are required not to change the overall exterior architecture as the building is considered to contribute to the uniqueness of the local urban environment and therefore listed. The reduced energy demand, related to individual measures, is estimated and building physics requirements are addressed together with the economic options for evaluating the profitability.
\end{abstract}

Keywords: Measures, energy demand, building physics requirements, retrofit, brick, building.

\section{INTRODUCTION}

Tightened requirements to the thermal insulation of new buildings and the resulting demand for a reduction of the energy consumption for heating and comfort, in order to reduce $\mathrm{CO} 2$ emissions, mean that existing and especially older buildings are categorised as having a very low thermal standard compared with today's requirements. Therefore, there is an increased interest in improving the thermal insulation standard of many existing and older buildings. However, many older buildings have restrictions that protect the entire building or that protect only its exterior. Therefore customised solutions reducing the energy consumption are needed for these buildings. Moreover, close attention should focus on preventing degradation of the existing construction when the energy needed for heating and thermal comfort of a building decreases, as a result of measures to improve the thermal insulation. Besides lower heating costs and reduced $\mathrm{CO} 2$ emissions, the improvements of the standard of insulation could contribute to the elimination of other aspects of discomfort.

The aim of the paper is to show solutions that improve the thermal insulation standard of a building with a listed exterior facade. The paper includes technical solutions for improving the thermal insulation standard by showing customised thermal insulation measures of the building envelope. It also addresses issues that must be considered in order to prevent moisture-related degradation of the original building. Furthermore, a simple and accurate method for estimating the decreased energy demand after improvements is applied. Finally, the profitability of the measures is evaluated.

The paper is based on guidelines on how to improve the thermal insulation of existing buildings and blocks of flats published by the Danish Building Research Institute [1].

*Address correspondence to this author at the Danish Building Research Institute, Department of Construction and Health at Aalborg University, Hørsholm, Denmark; Tel: +45 99402272; Fax: +45 45867535;

E-mail: tvr@sbi.dk

\section{BACKGROUND}

In Denmark requirements to the thermal insulation of buildings has been significantly tightened over the last 30 years. Before the introduction of the first Danish Building Regulations [2], which came into force in 1961, no requirements to the thermal insulation of buildings existed. In fact, the first Danish Building Regulations did not focus on the energy consumption of buildings. The average coefficient of heat transmission was given for primary building components such as exterior walls, ground slabs and for roof constructions that corresponded well with the existing building tradition. Fig. (1) shows that the requirements to the thermal insulation of buildings remained much less stringent up to 1977 compared with today's requirements.

The average coefficient of heat transmission was tightened several times in the run-up to 2010. In 2006 individual requirements for the average coefficients of heat transmission and of building components were changed to requirements covering the aggregate energy consumption of buildings [3]. The tightened energy provisions introduced in 2006 and 2010, see Fig. (1), were both estimated to result in an

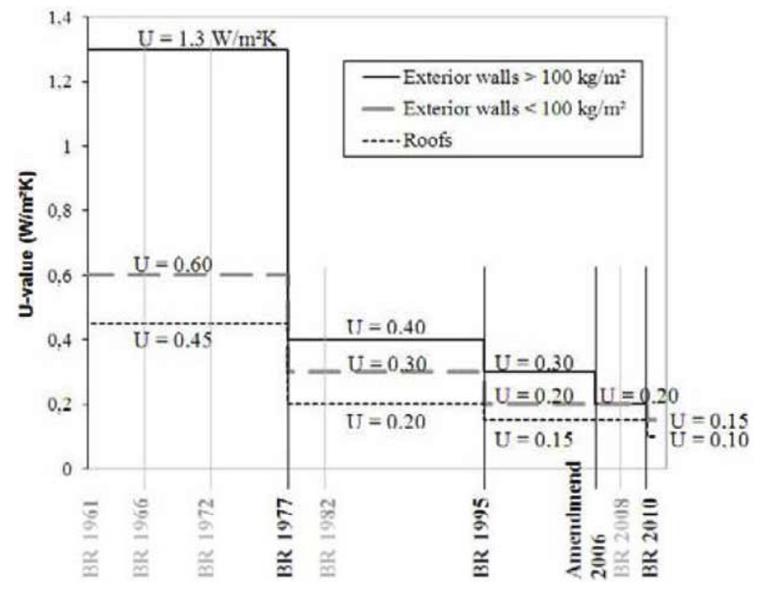

Fig. (1). The development of requirements to $U$-values $\left(W / \mathrm{m}^{2} \mathrm{~K}\right)$ in Denmark shown for exterior walls and roofs. 


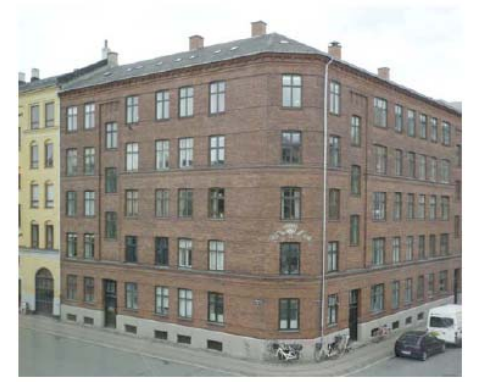

Fig. (2). Multi-storey building with flats constructed in 1900.

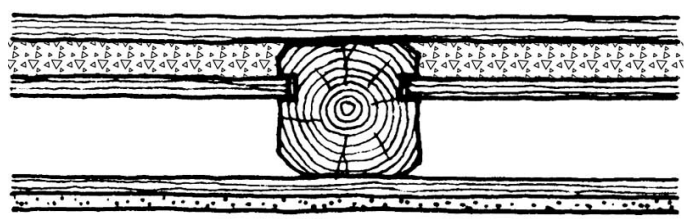

Fig. (3). Horizontal partition includes timber beams. From the top: floor board, clay infill, wooden boards, empty space, wooden boards and a layer of plaster on straw. The timber beams were of a good quality with the dimensions $200 \mathrm{~mm}$ by $200 \mathrm{~mm}$ with a tolerance from top to bottom of $6.25 \mathrm{~mm}$.

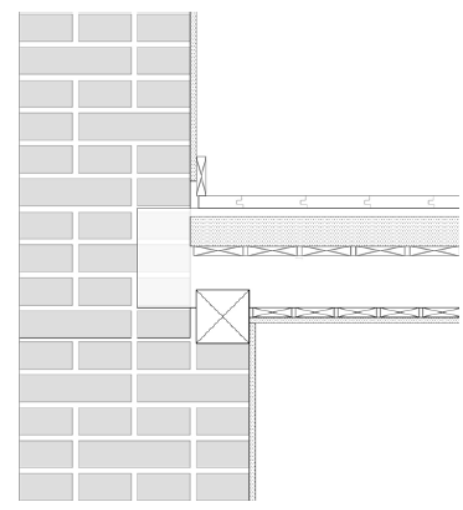

Fig. (4). Vertical section of the joint between the exterior loadbearing wall, which was the facade, and the horizontal partition. The exterior wall was a solid brick wall that decreased in thickness by half a brick every two floors. The timber beams reached into the brick wall. The structure of the horizontal partition is shown in Fig. (3).

energy reduction of $25 \%$ for new buildings compared with buildings constructed according to the former editions of the Danish Building Regulations [4-6].

This means that buildings older than 30 years are outdated with respect to their thermal insulation standard and their energy consumption. A significant reduction of $\mathrm{CO} 2$ emissions must include a reduction of the energy consumption for existing and especially older buildings [7].

Attention must focus especially on buildings with solid brick walls as these buildings have a low thermal standard. Buildings with solid brick walls were constructed in the period between 1850 and 1920 and many of these building are today recognised as buildings whose architecture contributes significantly to the uniqueness of the local urban environment. Approximately $20 \%$ of all dwellings registered in Denmark today are located in buildings dating from that period [8]. These buildings have typically not been retrofitted and with time it has become ever more obvious that they

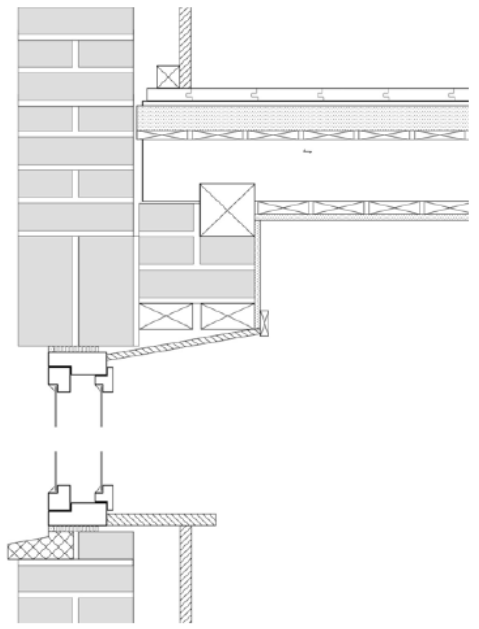

Fig. (5). Vertical section of the joint between the loadbearing exterior wall and the horizontal partition at the window wall. The structure of the horizontal partition is shown in Fig. (3).

need customised improvement of the thermal insulation to prevent that degradation occurs after measures have been implemented. Such a building has been considered for the case study presented and is shown in Fig. (2).

The number of dwellings constructed between 1850 and 1920 has not diminished significantly and has stayed fairly stable for the last 25 years.

Upgrading of the insulation standard is supported by the Danish Building Regulations [6]. The Danish Building Regulations implement the EU Directive on Energy Performance of Buildings, (EPBD) and stipulates that when major works are carried out on the building envelope, the insulation should be increased to a level comparable with the requirements governing new buildings, buildings with a changed use and extensions of buildings. The extra costs resulting from such improvement works must be economically profitable for the owner and the tenants in relation to service life and energy price. Moreover, degradation of the building from moisture must not occur as a result of improving the thermal insulation. The issue of economic profitability significantly reduces the effect of the Danish Building Regulations in practice.

\section{BUILDING DESCRIPTION}

The built-up area of the building was $9 \mathrm{~m} \times 64 \mathrm{~m}$ with one free house end. The building included 5 floors and a basement, 4 staircases; the floor height was $2.87 \mathrm{~m}$ between ceilings. There were 240 windows, each $1.09 \mathrm{~m}$ wide and $1.61 \mathrm{~m}$ high, see Fig. (2). The building had an exterior solid brick wall and a horizontal partition of timber beams, see Fig. (3). The brickwork of the exterior wall was three bricks in thickness at the base of the building decreasing to one and a half bricks at the top floor, see Fig. (4). The loadbearing exterior wall supported the timber beams, the solid brick wall decreased in thickness by half a brick every two storeys. The timber beams reached into the brick wall, see Fig. (4), and at the top floor of the building, the protecting brick is half a brick. The window wall under the windows was one brick in thickness, see Fig. (5). The non-loadbearing house ends had a thickness of one and a half bricks, see Fig. (6). 


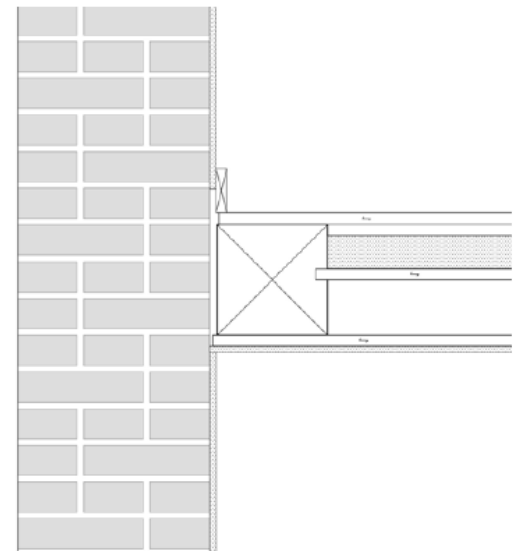

Fig. (6). Vertical section of the joint between the horizontal partition and the non-loadbearing house end. The structure of the horizontal partition is shown in Fig. (3).

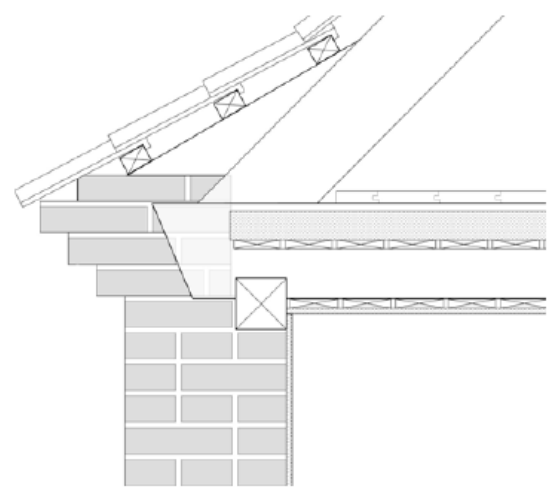

Fig. (7). Vertical section of the joint between the base of the roof at the horizontal partition and the loadbearing exterior wall. The structure of the horizontal partition is shown in Fig. (3).

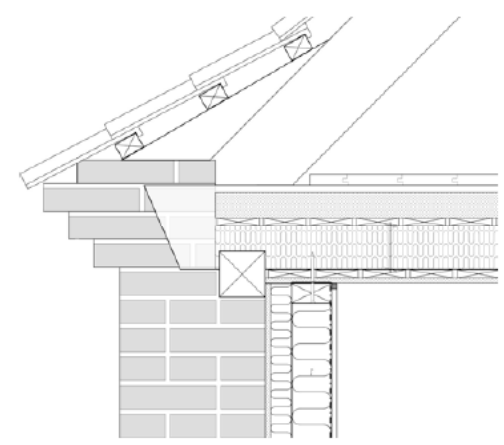

Fig. (8). Vertical section of the joint between the base of the roof at the horizontal partition and the loadbearing exterior wall. Improvement of the thermal insulation of the horizontal partition was carried out by blowing loose-fill mineral fibre insulation into the cavity between the timber beams underneath the clay infill. The joint between the loadbearing wall and the horizontal partition after improved thermal insulation is shown as well. The loadbearing wall was the facade of the building.

The building had a basement and a cold attic room. The roof was a double-pitched roof with a 45 degree angle. The vertical section of the junction between the bases of the roof at the loadbearing exterior wall at the facade is shown in Fig. (7). The joint of the roof base at the non-loadbearing house end was similar to the joint of the horizontal partition at the non-loadbearing house end, see Fig. (6).

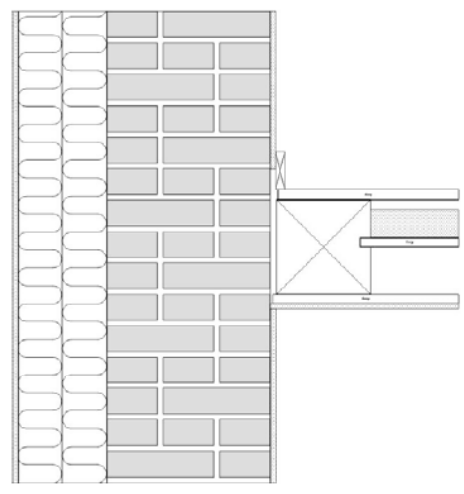

Fig. (9). Vertical section of the joint between the horizontal partition and the free non-loadbearing house end after improved thermal insulation measures.

The basement was originally used for storage e.g. coal for heating. Today basements like these are used for storage of bicycles and baby carriages and for accommodating facilities for washing. The basement was warm as it was heated by uninsulated and poorly insulated installations for heating.

\section{MEASURES}

The building was recognised as a building whose architecture contributes significantly to the uniqueness of the local urban environment, and therefore measures to improve the thermal insulation of the building envelope had to be carried out on the internal side of the external wall. However, at the free house end measures could be carried out on the outside. When designing the solution for the measures, special attention should be given to the prevention of condensation in the exterior wall due to air leakage and moisture, penetrating into the building envelope from the inside. It had to be realised that it might not be possible to eliminate thermal bridges when carrying out measures to improve the thermal insulation. In some cases thermal bridges can be used to maintain a high temperature level at critical locations in the building envelope and thereby decrease the moisture level.

Fig. (8) shows the improved thermal insulation system that was used for the loadbearing facade, which consisted of a timber stud frame with $95 \mathrm{~mm}$ mineral fibre insulation. The thermal conductivity of the mineral fibre insulation was $0.037 \mathrm{~W} / \mathrm{mK}$. The timber stud frame was attached to the horizontal partition between the individual floors of the building and kept clear of the exterior wall of the building envelope. The cavity between the timber stud frame and the exterior wall was filled with mineral fibre insulation. To prevent air and moisture from penetrating into the insulated exterior wall from the inside, an airtight shell was established by a $0.2 \mathrm{~mm}$ polyethylene foil that also served as the vapour barrier. It was crucial that the foil was located at the warm side of the dew point and that the joints between the sheets of foil and joints were airtight and securely fixed [7]. Towards the bottom of the timber stud frame wall, the foil was extended to the exterior brick wall and fixed airtight by a lath. At the top section of the timber frame wall, the foil was fixed airtight to the top rail of the timber stud frame, which was fixed airtight to the ceiling. The plaster at the ceiling was intact and without cracks. Fig. (9) shows the im- 


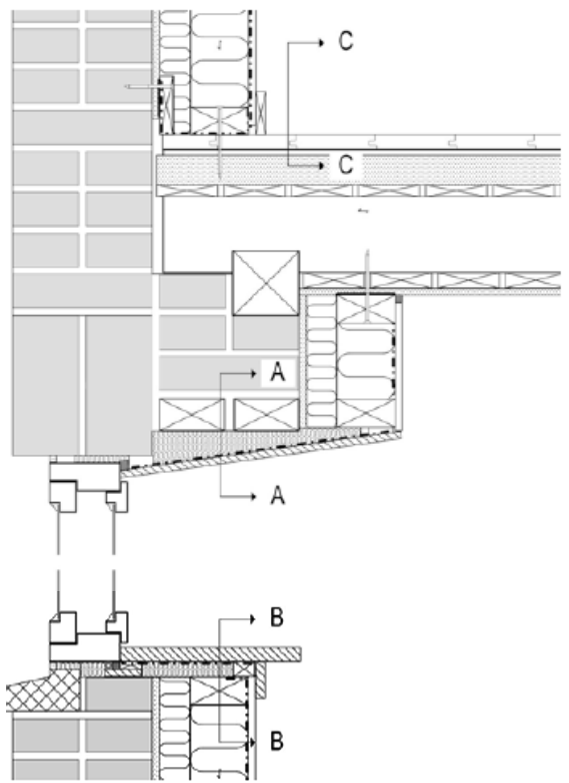

Fig. (10). Vertical section of the joint between the loadbearing exterior wall and the horizontal partition at the window wall after improvement of the thermal insulation. Sectional view of sections A-A, B-B and C-C, are shown in Fig. (11).
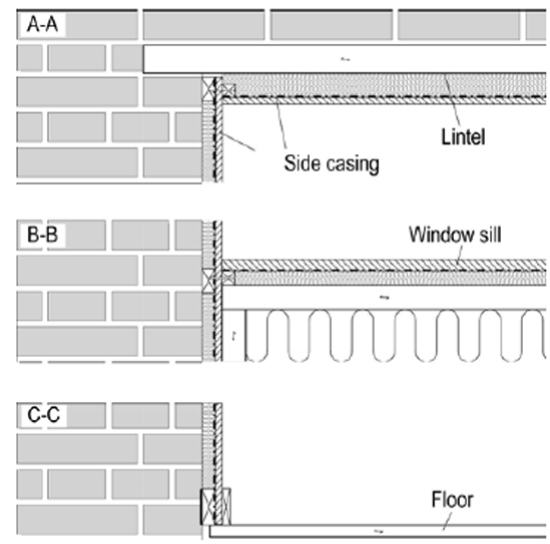

Fig. (11). Sectional view of sections A-A, B-B and C-C shown in Fig. (10).

proved thermal insulation system that was used for the nonloadbearing wall at the house end, which consisted of 195 $\mathrm{mm}$ mineral fibre insulation covered by a layer of plaster on the exterior side. The thermal conductivity of the mineral fibre insulation was $0.037 \mathrm{~W} / \mathrm{mK}$.

Improvement of the thermal insulation towards the cold attic room was carried out by blowing loose-fill mineral fibre insulation into the cavity between the timber beams, see Fig. (8). The thermal conductivity of the loose-fill mineral fibre insulation was $0.044 \mathrm{~W} / \mathrm{mK}$. The cavity accommodated 100 $\mathrm{mm}$ mineral fibre insulation.

Fig. (10) shows improved thermal insulation measures where the insulation was extended to the window by insulation located behind the narrow sill. The insulation located behind the narrow sill was placed there in order to minimise the thermal loss in the joint between the window and the exterior wall. Fig. (11) shows sectional views of Fig. (10). Existing windows with a U-value equal to $2.7 \mathrm{~W} / \mathrm{m}^{2} \mathrm{~K}$ were replaced by new windows that had a $\mathrm{U}$-value equal to $\mathrm{U}=1.6$ $\mathrm{W} / \mathrm{m}^{2} \mathrm{~K}$.

Improvements of the thermal insulation of the horizontal partition towards the basement was not of relevance since the basement was warm. Installations including pipes and boiler were not retrofitted.

\section{CALCULATION OF SUPPLIED ENERGY}

To determine whether a specific improvement is profitable, it is important to know how much less energy is necessary in order to satisfy human demand for heating and comfort. The reduction in the transmission loss can be calculated quite simply from the reduced overall coefficient of heat transmissions, the reduction of the U-values, and the number of degree-days. However, such a calculation does not take into account the increased relative contributions from solar gain, electric appliances and people when the transmission loss is reduced. For this reason, the reduction of the demand for energy is bigger than the reduction of the transmission loss, which increases the efficiency of the improved thermal insulation.

\subsection{Calculation Procedure}

The energy supplied to a building is usually calculated by a PC program, Be06 [9], which in effect is an integral part of the Danish Building Regulations and consequently an important part of the implementation of the EPBD in Denmark. The calculations were performed in accordance with the mandatory calculation procedure described in guidelines on energy demand of buildings published by the Danish Building Research Institute, SBi [9]. The software uses the mandatory calculation core also developed by the Danish Building Research Institute. Be06 calculates the energy demand expected for operating the heating and air-conditioning systems in all types of buildings e.g. houses, blocks of flats, offices, institutions, schools, shops and workshops. The Be06 software calculates the energy supply required by a building for space heating, ventilation, cooling, domestic hot water and artificial lighting depending on e.g. building design, building envelope, access to daylight, ventilation system, heating installation and energy supply including alternatives like solar heating, solar power and heat pumps. All two-dimensional transmission coefficients were determined by using a PC and the finite difference program HEAT2 version 5.0 [10] in accordance with relevant CEN standards.

The reduction of the energy supply obtainable by improved thermal insulation of the individual building components was calculate by using a robust and simple method. It provided useful results in agreement with $\mathrm{Be} 06$ calculations for determining the "effective heat loss" denoted Q $\left[\mathrm{kWh} / \mathrm{m}^{2}\right][11]$. The simple method [11] can determine the change in energy demand of a building before improving the thermal insulation standard and after measures were carried out that improved the thermal insulation. The method is verified for a virtual building, where all measures are included in one calculation and compared with the sum of the measures. The error is shown to be less than $1 \%$. The difference between the calculated energy demand represents the reduction of the energy demand after measures were carried out that improved the thermal insulation. By introducing one measurement at a time in the model, the effect of the 
Table 1. Example of Calculation of Potential Savings of Energy Demand

\begin{tabular}{|c|c|c|c|c|c|c|c|}
\hline \multirow[t]{2}{*}{ Component } & \multirow[t]{2}{*}{$\begin{array}{l}\text { Detail as in } \\
\text { Fig. no. }\end{array}$} & \multirow[t]{2}{*}{$\begin{array}{l}\text { Area or } \\
\text { length }\end{array}$} & \multirow[t]{2}{*}{$\begin{array}{l}\text { Improved thermal } \\
\text { insulation thickness }\end{array}$} & \multicolumn{2}{|c|}{$\begin{array}{l}\text { Effective heat loss, } Q \\
\mathrm{kWh} / \mathrm{m}^{2} \text { or } \mathrm{kWh} / \mathrm{m}\end{array}$} & \multirow[t]{2}{*}{$\begin{array}{c}\text { Overall reduction } \\
\text { kWh/year }\end{array}$} & \multirow[t]{2}{*}{$\begin{array}{l}\text { Reduction per } \mathrm{m}^{2} \\
\text { floor area } \mathrm{kWh} / \mathrm{m}^{2}\end{array}$} \\
\hline & & & & Original & $\begin{array}{l}\text { Improved } \\
\text { insulation }\end{array}$ & & \\
\hline Facade, $1 \frac{1}{2}$ bricks & 4,8 & $434 \mathrm{~m}^{2}$ & $95 \mathrm{~mm}$ & 131 & 28 & 44702 & 15.5 \\
\hline Facade, 2 bricks & 4,8 & $434 \mathrm{~m}^{2}$ & $95 \mathrm{~mm}$ & 103 & 28 & 32550 & 11.3 \\
\hline Facade, $2 \frac{1}{2}$ bricks & & $217 \mathrm{~m}^{2}$ & $95 \mathrm{~mm}$ & 85 & 28 & 12369 & 4.3 \\
\hline Window wall & 5,10 & $330 \mathrm{~m}^{2}$ & $95 \mathrm{~mm}$ & 180 & 28 & 50160 & 17.4 \\
\hline Free house end & 6,9 & $129 \mathrm{~m}^{2}$ & $195 \mathrm{~mm}$ & 131 & 17 & 14706 & 5.1 \\
\hline Windows, replaced & $\begin{array}{l}\mathrm{U}=2.7 \\
\mathrm{~W} / \mathrm{m}^{2} \mathrm{~K}\end{array}$ & $421 \mathrm{~m}^{2}$ & $\mathrm{U}=1.6 \mathrm{~W} / \mathrm{m}^{2} \mathrm{~K}$ & 138 & 55 & 34943 & 12.1 \\
\hline Roof & 7,8 & $576 \mathrm{~m}^{2}$ & $100 \mathrm{~mm}$ & 65 & 26 & 22464 & 7.8 \\
\hline $\begin{array}{l}\text { Window sill, } 1^{1 / 2} \\
\text { bricks }\end{array}$ & 10,11 & $518 \mathrm{~m}$ & $15 \mathrm{~mm}$ & 9 & 11 & -1036 & -0.4 \\
\hline $\begin{array}{l}\text { Window sill, } 2 \\
\text { bricks }\end{array}$ & & $518 \mathrm{~m}$ & $15 \mathrm{~mm}$ & 13 & 16 & -1554 & -0.5 \\
\hline $\begin{array}{l}\text { Window sill, } 2^{1 / 2} 2 \\
\text { bricks }\end{array}$ & & $259 \mathrm{~m}$ & $15 \mathrm{~mm}$ & 16 & 21 & -1295 & -0.4 \\
\hline $\begin{array}{l}\text { Spandrel edge at } \\
\text { window wall }\end{array}$ & & $605 \mathrm{~m}$ & $95 \mathrm{~mm}$ & 0 & 6 & -3630 & -1.3 \\
\hline Roof base, facade & 7,8 & $128 \mathrm{~m}$ & $100 \mathrm{~mm}$ & -39 & -3 & -4608 & -1.6 \\
\hline $\begin{array}{c}\text { Roof base, house } \\
\text { end }\end{array}$ & 6,9 & $9 \mathrm{~m}$ & $100 \mathrm{~mm}$ & -13 & -9 & -36 & $\sim 0$ \\
\hline $\begin{array}{l}\text { Horizontal partition } \\
\text { floor edge }\end{array}$ & $\begin{array}{l}4,6 \\
8,9\end{array}$ & $548 \mathrm{~m}$ & & 0 & 11 & -6028 & -2.1 \\
\hline $\begin{array}{l}\text { Party wall connec- } \\
\operatorname{tion}^{\oplus}, 1 / 2 \text { brick }\end{array}$ & & $459 \mathrm{~m}$ & & 0 & 10 & -4590 & -1.6 \\
\hline $\begin{array}{l}\text { Party wall connec- } \\
\text { tion }^{\oplus}, 1 \text { brick }\end{array}$ & & $129 \mathrm{~m}$ & & 0 & 14 & -1806 & -0.6 \\
\hline Sum 5 floors & & $2880 \mathrm{~m}^{2}$ & & & & 187311 & 65.0 \\
\hline
\end{tabular}

${ }^{\vartheta}$ Determined as $\left(\mathrm{Q}_{\text {original }}-\mathrm{Q}_{\text {improved insulation }}\right) \mathrm{x}$ Area or Length.

${ }^{\oplus}$ The party wall connection is where interior walls of brick were connected to the exterior wall

urement at a time in the model, the effect of the individual measure was revealed. The effective heat loss due to thermal bridges was calculated in the same way and was related to their length. Irregularities around thermal bridges were included as loss per metre. These contributions were added to the heat loss as loss per metre of floor edge.

\subsection{Calculation of Reduced Energy Demand}

The ventilation rate was 0.7 times per hour. Table 1 lists the relevant areas and lengths; it also specifies measures by listing numbers referring to figures.

\section{REQUIREMENTS}

Measures will change the overall conditions of existing constructions, so the risk of introducing degradation mechanism must be taken into consideration. Some measures might not be advisable as they constitute too high a risk of degradation of the existing construction. When improving the thermal insulation of the building envelope, it is of crucial importance to make use of measures that prevent moisture problems that subsequently can occur and cause degradation of the existing construction. In order to reduce the risk of damage to original constructions, the first step before improving the thermal envelope is to examine the original construction. Prior to carrying out improvements of the thermal insulation, a critical examination of the building must ensure that the building is suitable for the planned measures. If it is not suitable, additional work must be carried out to comply with the building physics requirements for carrying out the measurements. Improvements of the thermal insulation will change the overall condition of the existing construction. Therefore, special attention must be given to prevent that problems related to temperature decrease and moisture increase cause degradation for the improved, insulated building envelope. An important issue is whether or not lowering the temperature of the brick wall by adding thermal insulation on the inside of the external wall will reduce the drying potential to a level that exposes the wall to the risk of water damage and spalling. Therefore, attention must be given to the prevention of condensation in the exterior wall due to air leakage and moisture from penetrating into the building en- 


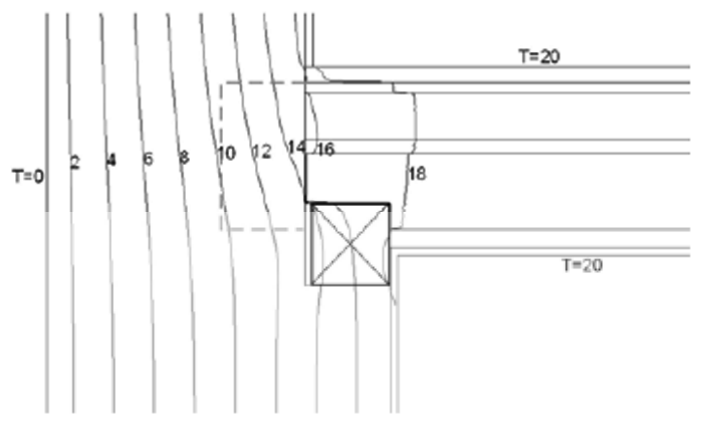

Fig. (12). Vertical section of the original joint. Isotherm curves are shown from where the timber beam of the horizontal partition reaches into the exterior loadbearing wall.

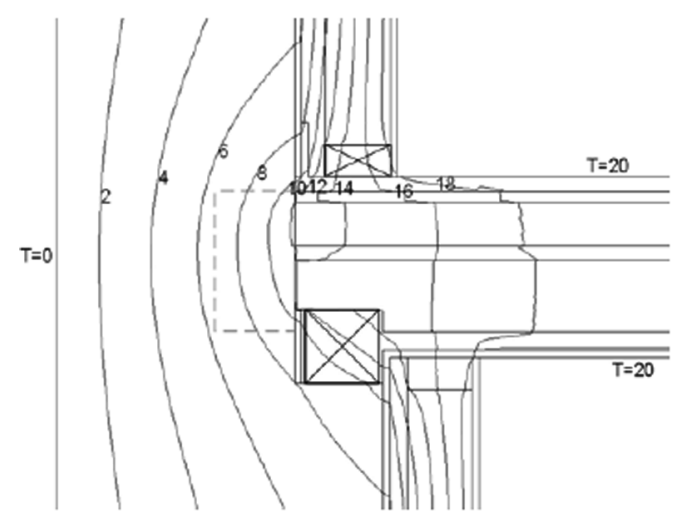

Fig. (13). Vertical section of the joint after improvement of the thermal insulation with $95 \mathrm{~mm}$ mineral fibre insulation.

velope from the inside [12] as well from the outside. Special attention should be given to analysing locations like the location where the timber beam of the horizontal partition reaches into the brick wall, see Fig. (8) and Fig. (10). After improvement of the thermal insulation, such locations will be left with a colder environment than originally. Test methods that can be used for evaluating the wall system of the existing building including requirements of the test method. Application of the test method and interpretation of test results can be found [13], including historical test data that illustrate the use of the test methods that can be used for evaluating wall systems as well as the expected range of test results for existing and repaired wall systems.

\section{TEMPERATURE DECREASE CALCULATIONS}

Improvement of the thermal insulation changes the temperature within the building envelope. A decrease in temperature causes an increase in relative humidity. Local measures to improve the thermal insulation of the building envelope may not introduce critical humidity levels, thus avoiding degradation of and mould growth on the existing construction. In particular, investigations included measurements of the temperature of the existing exterior wall (7.1) and measurements of the temperature at the timber beams of the horizontal partition reaching into the existing load bearing exterior brick wall (7.2), after improvement of the thermal insulation. Calculations determining the isotherm curves within the exterior wall were carried out using a PC and the finite difference program HEAT2 version 5.0 [10] in accordance with the method described in Danish Standards [14].

\subsection{Temperature Decrease in Exterior Wall}

Improving the thermal insulation located at the interior side of the exterior wall caused a drop in the temperature in the existing exterior wall, see Fig. (8) and Fig. (10). Isotherm curves showed that after improvement of the thermal insulation the overall temperature dropped in the existing exterior brick wall, see Fig. (12) and Fig. (13). The temperature difference within the existing exterior brick wall decreased from approximately $18{ }^{\circ} \mathrm{C}$ before improvements to $4{ }^{\circ} \mathrm{C}$ after improvements of the thermal insulation of the exterior wall. The thermal insulation was improved with $95 \mathrm{~mm}$ mineral fibre insulation, and exposed to $0{ }^{\circ} \mathrm{C}$ at the outside and $20{ }^{\circ} \mathrm{C}$ at the inside of the building.

\subsection{Temperature Decrease at Horizontal Partition}

Isotherm curves from where the timber beam of the horizontal partition reaches into the exterior loadbearing brick wall are shown in Fig. (12) and Fig. (13). Fig. (12) before and Fig. (13) after improvement of the thermal insulation of the exterior wall, by $95 \mathrm{~mm}$ mineral fibre insulation. The temperature at the end of the timber beam was reduced from $10{ }^{\circ} \mathrm{C}$ before improvement of the thermal insulation to $7{ }^{\circ} \mathrm{C}$ after improvements.

\section{DISCUSSION}

When improving thermal insulation, it might not be possible to eliminate thermal bridges. However, in some cases thermal bridges can be used to maintain the temperature at a high temperature level at critical locations in the building envelope, thereby decreasing the moisture level, see Fig. (12) and Fig. (13). Besides heat loss, thermal bridges cause low internal surface temperatures, which in turn heighten the risk of mould growth. This occurs in particular where a solid brick wall has not been thermally improved and where the thickness of the brick wall and insulation thickness are reduced i.e. around the windows, see Fig. (10). Typically, thermal bridges occur at the joints of different building components where it is difficult to achieve continuity in the thermal insulation layer.

After improvement of the thermal insulation, the joint between the loadbearing wall and the horizontal partition showed a temperature decrease that should be noted. Assuming that at temperatures above $5{ }^{\circ} \mathrm{C}, 75 \% \mathrm{RH}$ can cause mould growth [15], the critical moisture content of the timber beam that reaches into the brick wall is $6 \mathrm{~g} / \mathrm{m}^{3}$ in winter and $13 \mathrm{~g} / \mathrm{m}^{3}$ in summer for normal weather conditions in Denmark [16]. The outdoor moisture content is at the highest level, $12 \mathrm{~g} / \mathrm{m}^{3}$, in summer (June to August) and decreases to the lowest level, $4 \mathrm{~g} / \mathrm{m}^{3}$, outdoors in winter (December to March) [16]. The outdoor moisture content was therefore not a risk, as long as the exterior solid brick wall did not lose its drying potential. As warm air with high moisture content from the inside could penetrate into the timber of the horizontal partition at the loadbearing facade, a risk of degradation was introduced. In such a case, it must be ensured and controlled that the moisture content indoors does not cause, or exceed, the critical conditions at the timber beam end, i.e. $20{ }^{\circ} \mathrm{C}, 35 \% \mathrm{RH}$ in winter and $75 \% \mathrm{RH}$ in summer [16]. The risk of degradation of the timber beam end is increased with critical moisture exposure for longer periods of time. Imple- 
mentation of monitoring equipment connected to an automatic control system of the indoor air is recommended. In many cases, establishing improvement of the thermal envelope will additionally give rise to new demands for control of the indoor environment.

The effective heat loss through components before and after establishing measures that improve the thermal insulation are given in Table 1 together with the overall reduction in energy demand per year. For reference, the reduction was also given per $\mathrm{m}^{2}$ floor area. The energy demand was reduced by $65 \mathrm{kWh} / \mathrm{m}^{2}$ by implementing the measures listed in Table 1 and was the difference between a calculated energy demand of $105 \mathrm{kWh} / \mathrm{m}^{2}$ before and a calculated energy demand of $40 \mathrm{kWh} / \mathrm{m}^{2}$ after improving the thermal insulation of all components.

The largest reduction of the calculated energy demand was related to the improved thermal insulation of the exterior walls. Improvement of the thermal insulation of the exterior walls resulted in a reduction in the calculated energy demand by $139781 \mathrm{kWh}$ per year. However, the reduction in the calculated energy demand should have been adjusted with the energy loss at the spandrel edge at the window wall, the horizontal partition floor edge and party wall connection that was $16054 \mathrm{kWh}$ per year. But still the improvement of the thermal insulation of the exterior walls was significant in reducing the demand for energy.

The most significant reduction of the effective heat loss occurred for the windows, where the energy loss was reduced from $138 \mathrm{kWh} / \mathrm{m}^{2}$ to $55 \mathrm{kWh} / \mathrm{m}^{2}$ and contributed with a reduction of the calculated energy demand of $34943 \mathrm{kWh}$ per year. This was due to the solar gain, which combined with the new windows almost equals the transmission loss. For the old windows, the net losses were much higher, but the solar gain still contributed significantly. The effective heat loss was therefore the difference between the transmission loss and the useable solar gain, both of a significant size.

Another big reduction of the calculated energy demand was related to the improved thermal insulation of the roof. The improved thermal insulation of the roof resulted in a reduction of the calculated energy demand by $22464 \mathrm{kWh}$ per year, where the energy loss was reduced from 65 $\mathrm{kWh} / \mathrm{m}^{2}$ to $26 \mathrm{kWh} / \mathrm{m}^{2}$. The energy loss through the roof was reduced, and at the same time it was found that the energy loss through the base of the roof increased. At the same time the effective heat loss, after the improvement of the thermal insulation, was found to be less negative than for the original construction. That the effective heat loss had a negative value along the base of the roof edge along the loadbearing facade and the house end was due to the Danish rules for calculating the heat loss. When calculating the heat loss, the height of the wall was considered to extend to the upper side of the attic floor for the improved horizontal partition towards the attic room, which was an extension of the height above the actual height.

For measures to be economically profitable for the owner, the cost of the measures must not exceed the savings obtained from the reduced demand for energy made over the lifetime of the implemented measures, i.e. exceeding esti- mated payback period. At an energy price of $0.133 € / \mathrm{kWh}$, using natural gas for heating, an interest rate of $6 \%$ and a payback period of 30 years the expenses for the measures must not exceed $343145 €$ as the savings of $24912 € /$ year has to be the instalment per year. The energy price used for the calculation was the energy price in Denmark 2011. The economic profitability varies greatly with the energy price and interest rate. Using an interest rate of $4 \%$ and a payback period of 30 years the expenses for the measures must not exceed $431003 €$ with the instalment of $24912 € /$ year. For the $343145 €$ in cash, the payback period was reduced to 13.8 years. Studies of external measures by replacing exterior walls including upgrading of window systems and thermal insulation seem more economically profitable with an estimated payback period of 14 years [17].

\section{CONCLUSIONS}

Durable methods were presented for improving the thermal insulation of a building constructed in 1900. The building was constructed with an exterior solid brick wall and a horizontal partition of timber beams. The building was constructed as a typical building constructed in the period from 1850 to 1920 . These buildings were constructed before requirements of thermal insulation, as we known them today, were important. The building was listed. Listing include only its exterior brick facade as the exterior architecture of the building was considered to contribute to the uniqueness of the local urban environment. It was demonstrated that the calculated effective heat loss - that is transmission and ventilation loss minus the useable part of solar gain and other free contributions - could be reduced by $62 \%$ just by improving the building envelope by means of viable measures. The heat loss did not reach today's requirements governing new buildings, but significant improvements were achieved.

When improving the thermal insulation standard of different building parts integrated in the building envelope by improving the thermal insulation and replacing windows, special attention must be given to the solutions for improvements both at the design stage and by critical examination of the building to prevent the risk of degradation of the existing construction. A critical examination of the building has to be carried out to ensure that the building is suitable for the intended measures to improve the thermal insulation. If not, additional work must be carried out to fulfil the building physics requirements for carrying out the measures.

It must be noted that a lowering of the temperature of the brick wall by adding a layer of insulation to the interior side of the exterior wall will change the overall condition of the existing construction. Special attention should be given to locations where e.g. the timber beam of the horizontal partition reaches into the brick wall.

When improving the thermal insulation of the building envelope it must be realised that it might not be possible to eliminate thermal bridges. However, in some cases thermal bridges can be used to keep the temperature at critical locations in the building envelope at a high temperature level, and by that means decrease the moisture level.

A method for simple estimation of the reduced energy demand for a specific measure was applied. The simple 
method revealed whether the measures were economically profitable for the owner. For the measures to be economically profitable, the cost of the measures must not exceed the savings obtained from the reduced energy demand over a reasonable payback period, and should be less than the lifetime of the measures carried out. Calculations showed measures to be economically profitable for $119.2 € / \mathrm{m}^{2}$ floor area with an estimated payback period of 30 years with an interest rate of $6 \%$. Using an interest rate of $4 \%$, calculations showed measures to be economically profitable for $149.7 € / \mathrm{m}^{2}$ floor area. The economic profitability varies greatly with the energy price and interest rate. For cash payment, the payback period decreases to 13.8 years.

\section{ACKNOWLEDGEMENTS}

The work on which this paper is based was supported by the Danish Ministry of Social Affairs and the Priority 1: Fostering Innovations of the Baltic Sea Region Programme 2007 - 2013. Dr Jørgen Munch-Andersen, Danish Timber Information Council, has been very helpful in discussing methods for determining energy savings.

\section{CONFLICT OF INTEREST}

None declared.

\section{REFERENCES}

[1] J. Munch-Andersen, "Efterisolering af Etageboliger" (Improving Insulation of Multistory Houses, in Danish), (SBi-Direction 221), Hørsholm, Danish Building Research Institute, 2008.

[2] "BR1961 National Agency for Enterprise and Construction, Bygningsreglement", (Danish Building Regulations 1961), Copenhagen, [with amendments], 1661. [Online]. Available: http://www.ebst.dk/file/31-31/bygningsreglementet_1961. pdf [In Danish].

[3] "Supplement no. 12 to the National Agency for Enterprise and Construction, Bygningsreglement," (Danish Building Regulations 1995), Copenhagen, [with amendments], 1995. [Online]. Available: http://www.eb-st.dk/file/3346/Tillaeg_12_til_BR_95.pdf [In Danish].

[4] "National Agency for Enterprise and Construction, Bygningsreglement," (Danish Building Regulations 1995), Copenhagen, [with amendments], 1995. [Online]. Available: http://www.ebst.dk/bygni-g-sreglement-et.dk/br95/0/42 [In Danish].

[5] "National Agency for Enterprise and Construction, Bygningsreglement", (Danish Building Regulations 2008), Copenhagen, [with amendments], 2008. [Online]. Available: http://www.ebst.dk/bygningsreglem-entet.dk/br07/0/42 [In Danish].

[6] "National Agency for Enterprise and Construction, Bygningsreglement", (Danish Building Regulations 2010), 2010. Copenhagen, [Online]. Available: http://www.ebst.dk/bygningsreglementet.dk [In Danish].

[7] T. V. Rasmussen, "Achieving airtightness of the building envelope in practice: An instrument to comply with the Kyoto protocol", In: Proceedings of the 4th international building physics conference: Energy efficiency and new approaches, 15-18 June 2009, Istanbul, Istanbul Technical University, pp. 145-150, 2009.

[8] "Statistics Demnark, Danmarks statistic", 2009. [Online]. Available: http://www.ds-t.dk/adm2006/External/Hkv/GetFileT4.aspx?sysrid $=48377$ [in Danish].

[9] S. Aggerholm, and K. Grau, Energy Demand of Buildings (SBi Direction 213), Hørsholm, Danish Building Research Institute, 2008.

[10] "HEAT2 - Heat transfer in two dimensions, BLOCON SWEDEN", Lund Group for Computational Building Physics, Department of Building Physics, Iliongränden 159, S-224 72 Lund, Sweden, www.blocon.se, www.buildingphysics.com, http://www.buildingphysics.com/index-filer/heat2.htm

[11] J. Munch-Andersen, "Improving thermal insulation of concrete sandwich buildings", Indoor and Built Environment, vol. 18, no. 5, 424-431, 2009

[12] N. E. Andersen, G. Christensen, and F. Nielsen, "Bygningers fugtisolering", (Moisture insulation of buildings, in Danish), (SBIDirection 178), Hørsholm , Building Research Institute, 1993.

[13] G. A Dalrymple, and A. R. Whitlock, "Applying C1601-06 "Standard Test Method for Field Determination of Water Penetration of Masonry Wall Surfaces in Practice", ASTM Special Technical Publication - Repair, Retrofit and Inspection of Building Exterior Wall Systems, vol. 1493 STP, 2009.

[14] Danish Standards, DS $418,6^{\text {th }}$ ed. Beregning af bygningers varmetab, Calculation of heat loss from buildings, Copenhagen, 2002, [In Danish].

[15] T. V. Rasmussen, M. H. Hansen, N. C. Bergsøe, and L. Gunnarsen, "Relative humidity in dwellings for senior citizens", In E. de Oliveira Fernandes, M. Gameiro da Silva, and J. Rosado Pinto Eds., Healthy Buildings HB 2006, Creating a healthy indoor environment for people, Proceedings, Vol. II, Indoor climate, Porto: ISIAQ. Lisboa, 4-8 June, 2006, pp. 181-186.

[16] N. E. Andersen, G. Christensen, and F. Nielsen, "Bygningers fugtisolering", (Moisture insulation of buildings, in Danish), (SBIDirection 178). Hørsholm, Building Research Institute, 1993.

[17] E. J. Peterson, and W. H. Blodgett, "Energy savings resulting from building envelope upgrades in mid-rise construction - a case study", In: Proceedings of Repair, Retrofit and Inspection of Building Exterior Wall Systems Conference, January 21 - 22 2006, ASTM Special Technical Publication - Repair, Retrofit and Inspection of Building Exterior Wall Systems, vol. 1493 STP, 2009, pp. 77-84. 